\begin{tabular}{|c|c|c|}
\hline & Int.J.Curr.Microbiol.App.Sci (2021) 10(10): 36-42 & \\
\hline$\frac{}{\text { EXCELLENT }}$ & $\begin{array}{l}\text { International Journal of Current Microbiology and Applied Sciences } \\
\text { ISSN: 2319-7706 Volume } \mathbf{1 0} \text { Number } \mathbf{1 0}(\mathbf{2 0 2 1 )} \\
\text { Journal homepage: http://www.ijcmas.com }\end{array}$ & 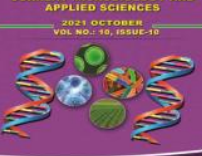 \\
\hline PUBLISHERS & & wwwijcmas.com \\
\hline
\end{tabular}

\title{
Physico-chemical and Cyanophitic Variation of Ganga Sagar Lake, Jabalpur
}

\author{
Preetraj Singh Patel ${ }^{1}$ and Balendra Pratap Singh ${ }^{2 *}$
}

${ }^{1}$ Government College, Budhani Sihore, M.P., India

${ }^{2}$ Rajabhoj Government College, Mandideep Raisen, M.P., India

*Corresponding author

Keywords

Cyanophyta,

Ganga Sagar Lake,

Jabalpur,

Physico-chemical

Article Info

Accepted:

05 September 2021

Available Online:

10 October 2021
The present studies focused on the Physico-chemical parameter and Cyanophitic diversity of Ganga Sagar Lake, Jabalpur. The physicochemical parameters like temperature, water temperature, D.O., $\mathrm{pH}$, free $\mathrm{CO}_{2}$, Total alkalinity, total hardness, calcium hardness, chloride, phosphate and nitrate were studied to analyze the Ganga Sagar Lake, Jabalpur. The study area selected was Cyanophitic diversity has been done with scientific name in this Lake. In these studies, an attempt has been made to identify the taxa of Cyanophyta in Pre-monsoon, monsoon, summer and Post monsoon from July 2017 to June 2019.

\section{Introduction}

Jabalpur is situated at a distance of $308 \mathrm{~km}$ from the capital city of Bhopal. It is located at $23^{\circ} 10^{\prime} 57^{\prime \prime} \mathrm{N}$ and $79^{\circ} 55^{\prime} 54^{\prime \prime} \mathrm{E}$. and MSL 410 M Latest archeological excavations have revealed that the city is nearly 4000 years old. Jabalpur is called the city of the lake at one time there were 52 lakes in Jabalpur, out of which 13 lakes are dried up. The Supatal Lake is situated in the Mahakausal region of Jabalpur. It lays behind the Ramayana Temple Garha Jabalpur. Surrounded by Hanumanbagh Temple nearby, NH-7 road, mountains, and temples. Every living organism needs water to survive. Plants need water to make food. All animals depend on plants for food either directly or indirectly. Therefore without water, all life forms will cease to exist. With the ever-increasing population, water is becoming a scarce commodity. To worsen this situation, the few available sources of water for consumption by living organisms are being depleted at an alarming rate. Careless release of wastes into water bodies is also a major problem today.

The water level of any water body mainly depends upon the climatic condition especially the rainfall in the catchments area, 
atmospheric temperature, evaporation and draw of water for domestic use or any other uses. The depth of water of the Ganga Sagar Lake, Jabalpur markedly decreases in summer due to evaporation loss as well as due to the draw of water for various uses. Studies conducted by Tamot (1994) revealed that the water level decreased gradually from October to June when the lowest level was reached.

Thereafter the level rises again during the rainy season in July to September. Reasons for such fluctuations are greater evaporation during the summer months, which are characterized by high temperature and low relative humidity. This study conducted during 1991-92 does confirm that transpiration loss of water was not significant, since macrophytic vegetation was absent.

Location Longitude $79^{\circ} 54^{\prime} 41^{\prime \prime} \mathrm{E}$, Latitude $23.09^{\circ} 28^{\prime \prime}$ N. Hydrology- Catchment area 18.636 hectares, Submergence area, 16.29 ha., Gross storage, 12.83 million cubic meters, Live storage 5.18 meters, Maximum depth 7.23 meters, Minimum depth 4.03 meters, Lowest still level (LSL) 2.69 ha., Full reservoir level (FRL) 0.18 meters, Water spread at FRL Approx. 0.76 ha.

\section{Materials and Methods}

Fortnightly collections of water samples were collected from all the stations i.e. from four sampling stations of Ganga Sagar Lake, Jabalpur. Parameters such as atmospheric temperature, water temperature, D.O., $\mathrm{pH}$ and $\mathrm{CO}_{2}$ were studied at the sampling stations as they are liable to change soon. Total alkalinity, total hardness, calcium hardness, chloride, phosphate, and nitrate parameters were analyzed in the laboratory on the same day of collection. All Physico-chemical parameters were determined adopting methods given by APHA (1998), NEERI (1986), Trivedi and Goyal (1986) and Adoni (1985).
The algal sample collection was carried out with the help of a truncated cone shape plankton net. The plankton net is made of bolting silk No.25 standard grade. This has an aperture size of $0.064 \mathrm{~mm}$. The concentrate was preserved in $4 \%$ formalin for study (Welch, 1952 and Lind, 1979).

\section{Observation}

Detail of the Physico-chemical characteristics of water of ponds the present study from July 2017 to June 2019 are given below. The data have been collected by the middle of the month when there was particularly no rainfall. The changes in Physico-chemical parameters are the direct and indirect indices of the quality of ponds water. The proper analysis of these factors enables us to characterize the degree of water pollution.

\section{Physico-chemical observations}

The temperature of Ganga Sagar Lake, Jabalpur did not differ much. It ranges between $14.0^{\circ} \mathrm{C}$ to $31.0^{\circ} \mathrm{C}$, the maximum temperature recorded in May 2008, during 2017-08, and second-year maximum temperature was recorded in May and June 2019 and minimum temperature value was recorded in January was both years. (Fig-1), Ganga Sagar Lake, Jabalpur the maximum D.O. value was $12.8 \mathrm{mg} /$ liter in March 2019 and minimum was $5.2 \mathrm{mg} / \mathrm{liter}$ in August, 2008 (Fig-2), pH of Ganga Sagar Lake, Jabalpur ranges from 7.4 to 8.6. The maximum value of $\mathrm{pH}$ was observed in Ganga Sagar Lake, Jabalpur in June. (Fig-3), free carbon dioxide value ranged recorded from $0.3 \mathrm{mg} /$ litre to $2.8 \mathrm{mg} /$ litre .

During 2017-18 the maximum free carbon dioxide value in June 2018 and minimum value in July 2017 and January 2018 and second-year the maximum value was 2.8 $\mathrm{mg} /$ liter in January 2019 and the minimum 
free carbon dioxide value recorded was 0.3 mg/liter in April 2019. In February and March 2019 free carbon dioxide value was nil (Fig4). In the present study, total alkalinity varied from 70 to $583 \mathrm{mg} / 1$ in the water of Ganga Sagar Lake, Jabalpur.

In the present study total alkalinity, highest values were recorded in February and April and the lowest alkalinity values were associated with August and September months (Fig-5), the calcium hardness value ranged recorded from $16.6 \mathrm{mg} / \mathrm{liter}$ to $41.5 \mathrm{mg} / \mathrm{liter}$. During 2017-18 the maximum calcium hardness value in June 2018 and minimum value in December 2017 and second-year the maximum value was $38.7 \mathrm{mg} / \mathrm{liter}$ in April 2019 and minimum value recorded was 22.8 mg/liter in November 2018 (Fig-6), chloride of Ganga Sagar Lake, Jabalpur did not differ much.

The chloride content showed the highest value of $70 \mathrm{mg} /$ liter in June 2018 and the lowest value of 46 mg/liter in February 2018 (Fig-7), chloride of Ganga Sagar Lake, Jabalpur did not differ much. The chloride content showed the highest value of $70 \mathrm{mg} /$ liter in June 2018 and the lowest value of $46 \mathrm{mg} / \mathrm{liter}$ in February 2018 (Fig-8), Phosphate content range from $0.70 \mathrm{mg} /$ liter to $1.16 \mathrm{mg} /$ liter.

In April and June 2019 the phosphate contents were minimum and in December 2017 the phosphate contents maximum (Fig-9), Nitrate content ranged from $0.008 \mathrm{mg} / \mathrm{liter}$ to 0.128 mg/liter. In April 2019 the nitrate contents were minimum and in May 2019 the nitrate contents were maximum (Fig-10).

\section{Results and Discussion}

Seasonal variations are evident in all the Physico-chemical parameters examined. Temperature is one of the most important ecological features that is a limiting factor for the growth and distribution of flora and fauna in any aquatic ecosystem.

Many workers while discussing the periodicity distribution and growth of Cyanophyta have laid much stress on the water temperature. According to Stroikine (1963), Hutchinson (1967), Hammer (1971) and Lin (1972) dense population blue-green algae are often associated with fairly high water temperature.

The distribution and growth of Cyanophyta members are attributed to a high temperature by Butcher (1924). Chakaraborty et al., (1959), Venkateshwarlu (1969) and Wilde and Tilly (1981) have also stressed the importance of water temperature in the periodicity of blue-green algae. Chu and Tiffany (1951) and Rao (1955) have stressed more on the significance of bright sunshine than temperature. Lin (1972) observed that relatively high summer water temperature favored the blue-green algal blooms and results in the high concentration of organic matter.

Pearsall (1932) have pointed out that bluegreen ware was observed in summer. Kaliyamurthi (1975) observed a peak of bluegreen algae in January to April and Singh and Swarup (1979) noted a peak in April to October, Zafar (1967), Biswas (1972), Khare (2017), Khare and Patil (2011), Mahajan et al., (2010) and Anand (1988) have reported that blue-green started increasing in early summer and attained their maxima in the middle of the summer season. According to Spancar and King (1989), the surface bloom of blue-green algae is present during the summer in many eutrophic lakes. Singhal (1986) found the Cyanophyta group dominating over other groups throughout the year and with the peak in April. In a previous observation on the lake, Valecha (1985) observed maxima growth of Cyanophyta in June and minima in winter. 
Fig.1 Temperature

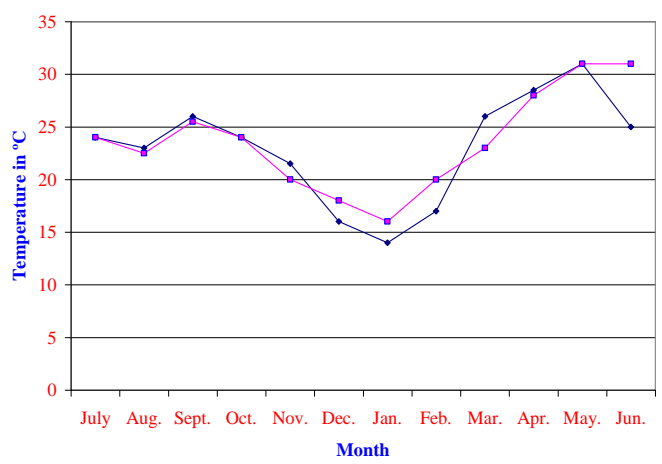

Fig.3 $\mathrm{pH}$ value

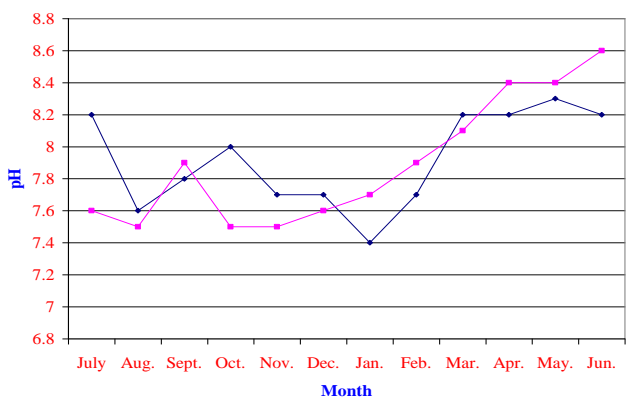

Fig.5 Total alkalinity

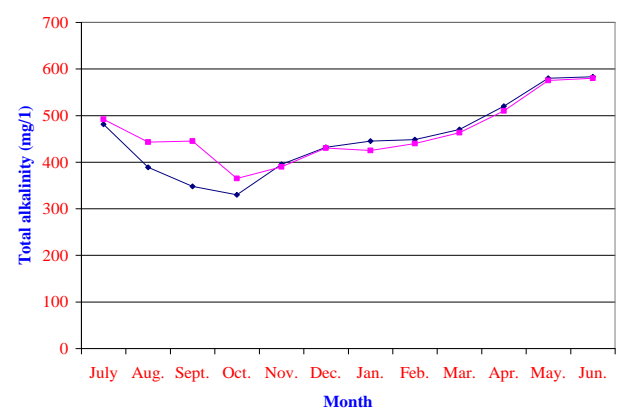

Fig.2 D.O. value

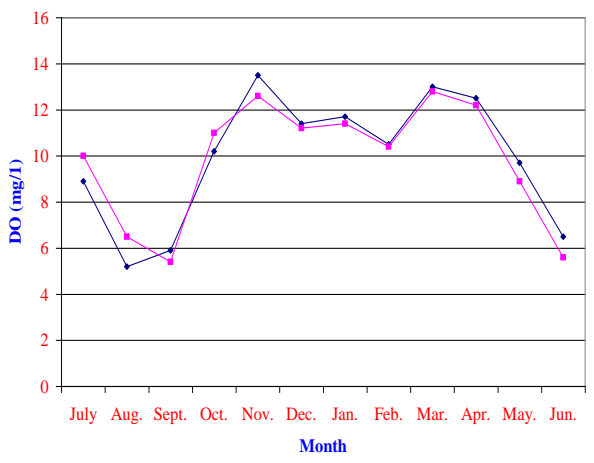

Fig.4 Free $\mathrm{CO}_{2}$ value

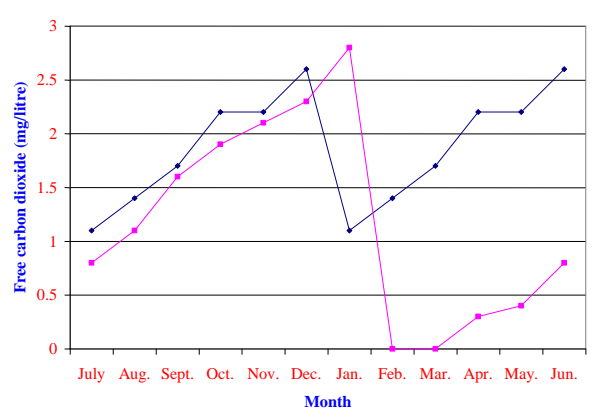

Fig.6 Total hardness value

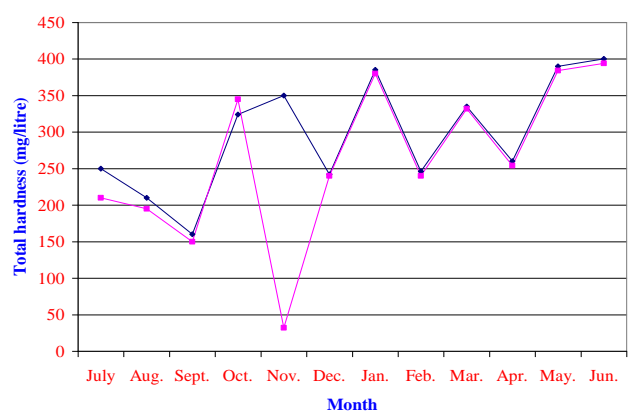


Fig.7 Calcium hardness value

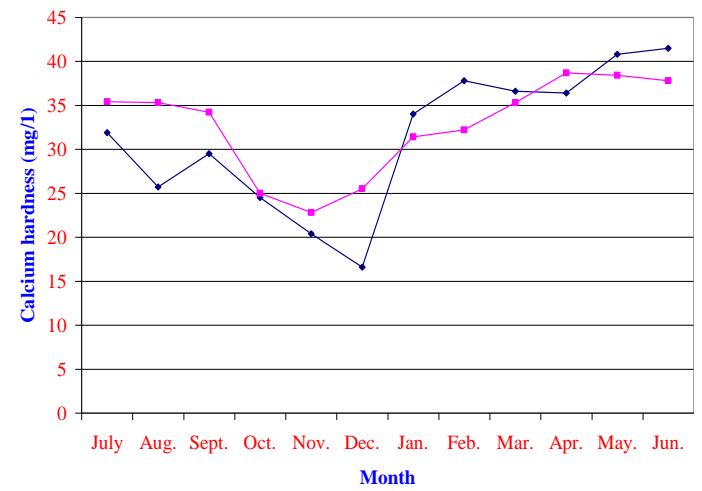

Fig.9 Phosphate content

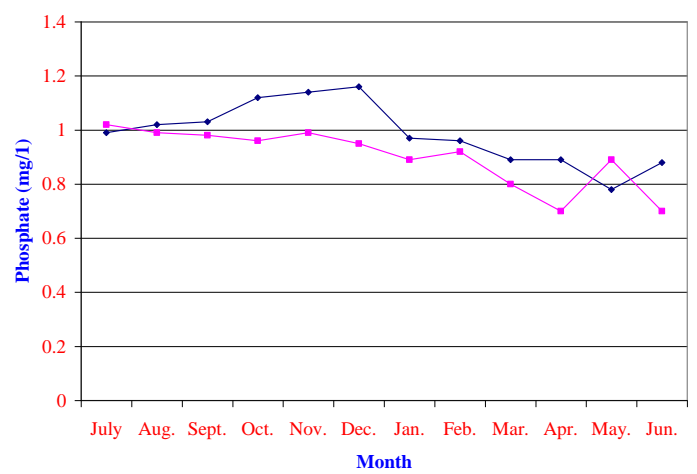

In April, May and June oxidizable organic matter was increased with the increased temperature. Rao (1955), Zafar (1967), Parmasivam and Sreenivasan (1981) have also confirmed the maximum of blue-greens with high concentrations of oxidizable organic matter. Desikachary (1959) supported that bicarbonates play a significant role in the maxima of Cyanophyceae.

In the present study of Ganga Sagar Lake, Jabalpur found forty seven species of order Chroococcales were found such as Microcystis aeruginosa, M. elongate, $M$. flos-aquae, $M$. protocystis, $\quad M . \quad$ pseudofilamentosa, Chroococcus limneticus, C. micrococcus, C. minor, C. minutus, C. turgidus, Gloeothece rupestris, G. samoensis, Aphanocapsa pulchra, Aphanothece nidulans, A. pallida, Dactylococcopsis fascicularis, D. raphidiodes,
Fig.8 Chloride content

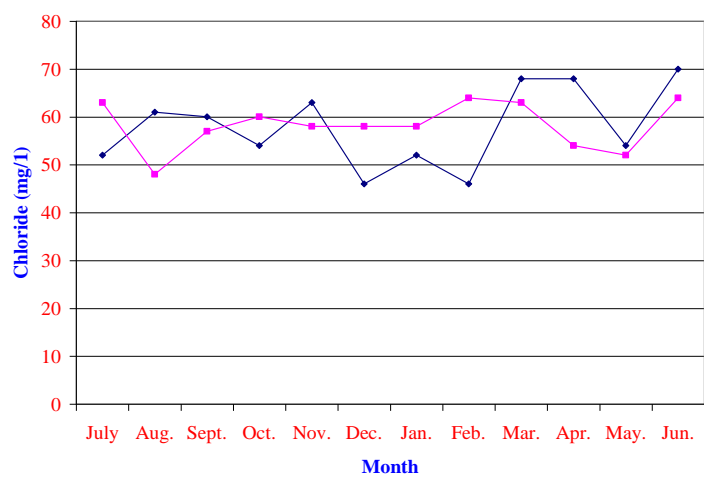

Fig.10 Nitrate content

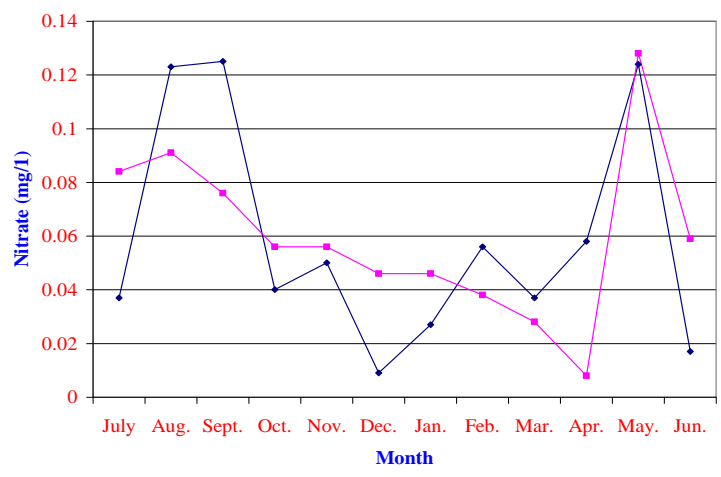

Gomposphaeria aponica, G. lacustris, Merismopedia elegans, $M$. glauca, $M$. punctata and M. tenuissima. Order Nostocales such as Arthospira jenneri, Oscillatoria acuta, $O$. amphibian, $O$. amphigranulata, $O$. chalybea, $O$. curviceps, $O$. foreaui, $O$. formosa, O. grunowiana, O. jasorevensis, $O$. laete-virens, $O$. laete-virens Gomont var. minimus, $O$. limosa, $O$. nigra, $O$. princeps, $O$. salina, O. sancta, O. subbrevis, Phormidium bohneri, P. calcicola, P. subincrustatum, Lyngbya hieronymusii, $L$. magnifica, $L$. majuscule, L. spirulinoides, Anabaenopsis arnoldii, Cylindrospermum doryphorum, $C$. indicum, C. sphaerica, Nostoc commune, N. sphericum, Anabaena ambigua, A. aphanizominoides, A. flos-aquae, A. spiroides, Raphidiopsis indica, Raphidiopsis mediterranea, Aulosira fritschii, Scytonema coactile, S. pascheri, Tolypothrix nodosa, 
Calothrix castellii, Rivularia aquatica, $R$. baceariana, R. dura, Gloeotrichia kurziana, and $G$. raciborskii var. kashiense.

The Ganga Sagar Lake, Jabalpur different genera in order of frequency of occurrence were Oscillatoria were dominant of 70 taxa and by predominance species of Microcystis, Chroococcus, and Merismopedia, Lyngby, Merismopedia and Anabaena in the peak period of Ganga Sagar Lake, Jabalpur.

\section{References}

Adoni, A. D. (1985). Workbook of limnology, Pratibha Publication. Sagar. M.P. India.

Adoni, A. D., Joshi G., Ghosh K., Chourasia S. K., Vaishya A. K., Yadav M., and Verma H. G., (1985). Work Book on Limnology, Pratibha Publishers, Sagar, $1-216$

Agarkar, M. S. (1975). Ecology of Algae of Bhopal. Ph.D. Thesis of A.P.S. University, Rewa, India

American Public Health Association, (1998): Standard method for the examination of water and wastewater, $20^{\text {th }}$ Edition, American Public Health Association Washington DC.

Anand, V. K. (1988). Limnology of freshwater algae of the Gadigarh Stream. Jammu. J. Curr. Bio. Sci. 5(1): 11-16.

Butcher, R. W. (1924). The plankton of river wharves (Yorkshire). Naturalist (175 180): 211- 214.

Chakaraborty, R. D., P. Roay and Singh, S. B. (1959). A quantitative study of the plankton and the physicochemical condition of the river Jamuna at Allahabad in 959. Indian Journal of Fisheries, 6(1):186-203.

Desikachary, T. V. (1959). Cyanophyta, I.C.A.R., New Delhi.

Geitler, L. (1932). Cyanophyceae. In $L$ Rabenhorst's Kryptogamen Flora,
Akademische Verlagsgesellschaft, Leipzig. 1196 pp.

Hammer, U. T. (1964). The Succession of Bloom Species of Blue-Green Algae and Some Casual Factors. Verh.Int.Verein Limnol., 15:829-836.

Hutchinson, G. E. (1967). A treatise on Limnology Vol. II. Introduction to lake biology and limnoplankon, New York. John Wiley and Sons, $1115 \mathrm{pp}$.

Khare, B. (2010). Ecology of Certain Small Water Bodies of Bhopal with Special Reference to Cyanophyta; Ph.D. thesis of Burkatullah University Bhopal, India

Khare, B. (2017). Hydrobiological studies in the upstream of river Kunda at Khargone, Madhya Pradesh. Env. Cons. Jou. 8 (1-2), pp. 81-83 (ISSN 0972-3099)

Khare, B. and Patil, P. (2011) Biodiversity of Cyanophytes of Jawahar Bal Udhyan Pond, Bhopal M.P. Indian Hydrobiology Journal Chennai.vol 14 (1) $8-21$.

Lin, C. K. (1972) Phytoplankton succession in a eutrophic lake with special reference to blue-green algal blooms. hydrobiol., $39: 321-334$.

Mahajan S. K. and Khare. B. Mahajan. P. (2010). Potential importance of Cyanophytes for sustainable development and exploitation in West Nimar of M.P., India Env. Cons. Jou. 11 (1 \& 2) 75-77, (ISSN 0972-3099)

Narayan, K. P., Shalini. Tiwari, Saurabh. Pabbi, Sunil. Dhar, Dolly Wattal., (2006). Biodiversity Analysis of Selected Cyanobacteria. Current Sci. Vol.91.No.7, 10.

NEERI (1986): Laboratory manual on water analysis. Nation Environmental Engineering Research Institute, Nagpur.

Oommachan, L. (1981). Ecological studies on lower lake of Bhopal (M.P.) with 
special reference to benthic fauna. Ph.D. Thesis, Bhopal University, Bhopal, India

Patil, P. (1982). An ecological study of the algal flora of lakes of Bhopal Ph.D. thesis, Bhopal University, Bhopal, India

Philipose, M. T. (1967). Chlorococcales. I.C.A.R., New Delhi.

Stroikine, V. C. (1963). Seasonal dynamics of
Phytoplankton in the Knibyshev reservoir. Kuivyshev, $3: 111-117$.

Trivedi, R. K. and Goyal, P. K. (1986). Chemical and biological methods for Water Pollution Studies. Environmental publications, Karad, India. P. 215.

Welch, P. S. (1952). Limnology. $2^{\text {nd }}$ Ed. Mc Gram Hill Book Co., Inc., 1 - 538.

\section{How to cite this article:}

Preetraj Singh Patel and Balendra Pratap Singh. 2021. Physico-chemical and Cyanophitic Variation of Ganga Sagar Lake, Jabalpur. Int.J.Curr.Microbiol.App.Sci. 10(10): 36-42. doi: https://doi.org/10.20546/ijcmas.2021.1010.005 